\title{
Economic Vision and Political Opposition in Malaysia, 1981-96: The Politics of the Mahathir Era
}

\author{
KHOO BOO TEIK
}

\begin{abstract}
This article approaches Malaysian politics from 1981 to 1996 in two ways. First it reviews important political events so as to capture the critical issues and political themes of four sub-periods of the 'Mahathir era'. Second, it interprets the consequences of the political struggles of the entire period in relation to major social and political developments in Malaysian society. For the latter part, the article considers such socio-political trends as the emergence of new political and bureaucratic alignments resulting from Mahathir's modernizing, industrializing and privatizing agenda; the centralization of executive power; authoritarianism; the formation of a state-capital alliance; and, the tensions felt in Mahathir's shift from the New Economic Policy to Vision $2020 .^{1}$
\end{abstract}

\section{Introduction}

If in these modern times one does not object in principle to thinking about any society in eponymous terms, then one could conceivably depict the past 16 years - since Datuk Seri Dr Mahathir Mohamad became Malaysia's fourth Prime Minister in July 1981 - as the 'Mahathir era' in Malaysian politics. There are at least three reasons why it may be substantively acceptable and not just convenient to do so, namely, that during that era,

- the transformation of the Malaysian political economy and society was profound;

- much of the politics was thematically dissimilar to that of previous periods; and

- Mahathir was a dominant figure in virtually all key aspects of social change and political contention. 
Furthermore, if one does not object to a division of the Mahathir era into several phases, according to a characterization of 'public sentiment', it may be said that the first phase of the era began in the early 1980s with considerable exuberance on the part of Mahathir himself, coupled with considerable bewilderment on the part of most Malaysians. However, in the current phase (that is, the 1990s), it would seem that Mahathir's exuberance has been translated into heightened expectations of the future, which are shared by very broad sections of Malaysian society. But in between the initial and the current phases of the Mahathir administration - that is, during the period of the mid- to late 1980s - lay two phases comprising several years of political struggle notable for their breadth, unpredictability and turbulence.

There are two central difficulties in reviewing the politics of the Mahathir era comprehensively in a short article. On the one hand, it would be a sterile chronicle that does not attempt a thematic interpretation of the events and conflicts, however disparate and unrelated some of them may seem to broader patterns and trends. On the other hand, the breadth and complexity of those conflicts make it risky to impose definitive interpretations without oversimplifying, over-rationalizing or over-determining what were chaotic and disorderly happenings in their time.

As a small aid to resolving these two central difficulties, a summary of major political events of that period, together with an indication of their principal outcomes and significance, is provided in Table 1, below. The list of events shown is not exhaustive, the brief characterizations of their outcomes and significance are contestable, and the methodological appropriateness of such a tabulation may even be questioned. But Table 1 may serve as a chronological guide for the non-specialist reader through the review that follows, and the interpretation that concludes this article. Perhaps at the outset, Table 1 may also serve as a reminder that the politics of the Mahathir period defy theoretically simplistic theses, such as the common assumption that inter-ethnic (that is, Malay and Chinese) rivalry alone supplies the only reliable parameters for understanding the character of Malaysian politics. ${ }^{2}$ 
Table 1: Political events, principal outcomes and significance, Malaysia, 1981-96

\begin{tabular}{|c|c|c|c|}
\hline Year(s) & Political event(s) & Principal outcome & Major significance \\
\hline \multirow[t]{2}{*}{1981} & $\begin{array}{l}\text { Hussein } \\
\text { Onn retires }\end{array}$ & $\begin{array}{l}\text { Mahathir becomes } \\
\text { Prime Minister }\end{array}$ & $\begin{array}{l}\text { commencement of } \\
\text { reformism and liberalism }\end{array}$ \\
\hline & $\begin{array}{l}\text { Musa-Razaleigh UMNO } \\
\text { Deputy President contest }\end{array}$ & $\begin{array}{l}\text { Musa wins and becomes } \\
\text { Deputy Prime Minister }\end{array}$ & $\begin{array}{l}\text { indications of UMNO's } \\
\text { factionalism }\end{array}$ \\
\hline 1982 & general election & $\begin{array}{l}\text { 1st Barisan Nasional victory } \\
\text { led by Mahathir }\end{array}$ & $\begin{array}{l}\text { announcement of } \\
\text { Mahathir's economic policies }\end{array}$ \\
\hline $1983-84$ & constitutional crisis & $\begin{array}{l}\text { stalemate between } \\
\text { UMNO and royalty }\end{array}$ & $\begin{array}{l}\text { centralization } \\
\text { of executive power }\end{array}$ \\
\hline 1984 & $\begin{array}{l}\text { 2nd Musa-Razaleigh } \\
\text { contest }\end{array}$ & $\begin{array}{l}\text { Musa wins again, Razaleigh } \\
\text { replaced as Finance Minister }\end{array}$ & $\begin{array}{l}\text { deepening } \\
\text { UMNO factionalism }\end{array}$ \\
\hline 1984-85 & MCA crisis & $\begin{array}{l}\text { Tan Koon Swan emerges } \\
\text { as MCA President }\end{array}$ & $\begin{array}{l}\text { Culmination of } \\
\text { business and politics in MCA }\end{array}$ \\
\hline $1984-86$ & Sabah crisis & $\begin{array}{l}\text { rise of Joseph Pairin Kitingan } \\
\text { and PBS }\end{array}$ & $\begin{array}{l}\text { Kadazan consciousness } \\
\text { and federal-state strains }\end{array}$ \\
\hline $1984-86$ & $\begin{array}{l}\text { politically related } \\
\text { financial scandals }\end{array}$ & $\begin{array}{l}\text { NGO-based criticism of } \\
\text { the executive }\end{array}$ & $\begin{array}{l}\text { spread of urban } \\
\text { middle-class disaffection }\end{array}$ \\
\hline 1985 & Memali incident & state assault on Islamic group & response to PAS's resurgence \\
\hline \multirow[t]{2}{*}{1986} & $\begin{array}{l}\text { Musa's resignation as } \\
\text { Deputy Prime Minister }\end{array}$ & $\begin{array}{l}\text { Ghafar Baba appointed } \\
\text { Deputy Prime Minister }\end{array}$ & $\begin{array}{l}\text { disaffection with Mahathir's } \\
\text { leadership }\end{array}$ \\
\hline & general election & UMNO's and DAP's triumphs & $\begin{array}{l}\text { Mahathir continues } \\
\text { in power, inter-ethnic divide }\end{array}$ \\
\hline $1986-87$ & formation of Team B & $\begin{array}{l}\text { Musa-Razaleigh's } \\
\text { challenge to Mahathir }\end{array}$ & UMNO's factionalism peaks \\
\hline \multirow[t]{2}{*}{1987} & UMNO election & Team A's narrow victory & $\begin{array}{l}\text { UMNO fully split } \\
\text { following purge of Team B }\end{array}$ \\
\hline & 'Operation Lalang' & mass arrests of opponents & $\begin{array}{l}\text { the end of Mahathirist } \\
\text { 'liberalism' }\end{array}$ \\
\hline \multirow[t]{2}{*}{1988} & UMNO's deregistration & formation of UMNO Baru & $\begin{array}{l}\text { Team B dissidents } \\
\text { excluded from UMNO Baru }\end{array}$ \\
\hline & judicial crisis & $\begin{array}{l}\text { impeachment of } \\
\text { Supreme Court judges }\end{array}$ & $\begin{array}{l}\text { culmination of } \\
\text { Mahathirist authoritarianism }\end{array}$ \\
\hline $1988-89$ & $\begin{array}{l}\text { continuing dissent against } \\
\text { UMNO Baru and Mahathir }\end{array}$ & $\begin{array}{l}\text { by-elections in several } \\
\text { states with victories }\end{array}$ & $\begin{array}{l}\text { inconclusive tests } \\
\text { of political strength }\end{array}$ \\
\hline 1989 & Semangat 46 formed & $\begin{array}{l}\text { Razaleigh leads } \\
\text { Team B in opposition }\end{array}$ & $\begin{array}{l}\text { basis of new coalitions } \\
\text { in opposition }\end{array}$ \\
\hline 1990 & general election & Barisan Nasional's victory & $\begin{array}{l}\text { 'two-coalition system' and PAS's } \\
\text { return in Kelantan }\end{array}$ \\
\hline 1991 & Vision 2020 unveiled & a new Mahathirist agenda & National Development Policy \\
\hline $1992-93$ & $\begin{array}{l}\text { assault by member of } \\
\text { royalty }\end{array}$ & royalty loses immunity & centralization of power \\
\hline 1993 & UMNO election & Wawasan Team victory & $\begin{array}{l}\text { Anwar becomes } \\
\text { Deputy Prime Minister }\end{array}$ \\
\hline 1994 & Sabah election & $\begin{array}{l}\text { PBS's narrow victory, } \\
\text { toppled by defections }\end{array}$ & new federal-state relations \\
\hline 1995 & general election & $\begin{array}{l}\text { Barisan Nasional's triumph, } \\
\text { DAP's defeat }\end{array}$ & success of Vision 2020 \\
\hline \multirow[t]{2}{*}{1996} & APU split & $\begin{array}{l}\text { Razaleigh and Semangat } 46 \\
\text { return to UMNO }\end{array}$ & PAS threatened in Kelantan \\
\hline & UMNO election & $\begin{array}{l}\text { Mahathir and } \\
\text { Anwar are unchallenged }\end{array}$ & $\begin{array}{l}\text { Anwar confirmed as Mahathir's } \\
\text { successor }\end{array}$ \\
\hline
\end{tabular}




\section{Phase 1, 1981-83: 'Vision' and the Pursuit of Nicdom ${ }^{3}$}

Mahathir succeeded Hussein Onn as UMNO's (United Malays National Organization's) President and Malaysia's Prime Minister in July 1981. To a Malaysian nation that could still remember the paternalistic ways of the first Prime Minister, Tunku Abdul Rahman, the imperturbable manner of the second Prime Minister, Tun Abdul Razak, and the self-effacing demeanour of the third Prime Minister, Tun Hussein Onn, Mahathir seemed to enter the office of the Prime Minister with a rude slamming of doors. Immediately in office, he initiated a well-publicized campaign of bureaucratic reform, diplomatic initiative, economic modernization, heavy industrialization and Islamization.

At the time many observers wondered if that overall campaign merely signalled a difference in the style of administration and leadership, between the low-key graces of Hussein Onn and the high-profile impatience of Mahathir. But fundamentally, the campaign promised 'content' with far-reaching ramifications - a thorough diagnosis of the socio-economic challenges facing Malaysia; an urgent solution modelled after Japanese managerial methods; and a vision of an industrial economy. In short, the campaign marked the beginning of a Mahathirist plan to embark Malaysia on the path to 'Nicdom', the prosperous position occupied by the so-called 'newly industrializing countries' (NICs) of East Asia.

From Mahathir's office came a series of catchy slogans which collectively set forth Mahathir's reformist drive, modernizing mission and Islamization, the best known being bersih, cekap dan amanah ('clean, efficient and trustworthy'), kepimpinan melalui teladan ('leadership by example'), and penyerapan nilai-nilai Islam ('absorption of Islamic values'). At this juncture, Mahathir's politics could be described as a form of 'tutelary populism' which sought to join a purposeful mass mobilization to his own enlightened leadership. As if creating a pattern of ripples radiating from himself, Mahathir called upon UMNO, the Barisan Nasional, the bureaucracy, the private sector, and, eventually, the entire population (Malays and non-Malays) to change their ways, redefine their priorities and strengthen their commitment to the nation. He especially wanted to create a nation of workaholics out of Malaysians who were repeatedly urged to emulate the 'Eastern work ethic' which Mahathir believed was the basis of the economic success of the East Asian NICs. In a society where ethnic suspicions were not easily set aside, Mahathir (who 
had previously been adulated by the Malays and feared by the Chinese as a 'Malay nationalist') strove to rise above ethnic partisanship partly by muting the inter-ethnic disputes which arose from time to time, and partly by setting an outward-oriented, Malaysian nationalist agenda best summed up by his 'Buy British last' and 'Look East' policies.

As a measure of his success in becoming all things to all men, Mahathir managed to rally to his banner diverse dissidents and opponents, including Anwar Ibrahim of the Angkatan Belia Islam Malaysia (ABIM, or Islamic Youth Force of Malaysia) and Kerk Choo Ting of the Dongjiaozong (an organization leading the Chinese education movement). ${ }^{4}$ As a measure of his broader political success Mahathir, for the first time, led the Barisan Nasional to an impressive victory in the 1982 general election. What was remarkable about that electoral victory was not that UMNO prevailed over its Malay/ Muslim opponent, Parti Islam SeMalaysia (PAS, or the Pan Malaysian Islamic Party), which had been expected, but that UMNO's main ethnic Chinese partner (the Malaysian Chinese Association, or MCA) regained a number of seats it had lost during the 1978 election to the Democratic Action Party (DAP), the leading opposition party which has always been rooted in the urban predominantly non-Malay constituencies.

By 1983 Mahathir had also revealed the extent of his economic policies. ${ }^{5}$ There were three major components to them:

- a heavy industrialization drive;

- a 'privatization' programme; and

- a 'Malaysia Incorporated' orientation.

The heavy industrialization drive - represented by a combination of a 'national car' project (Proton), a steel complex (Perwaja), two cement plants (in Perak and Pulau Langkawi), and three motorcycle engine factories - drew its inspiration from the success of South Korea's state-led late industrialization programme in particular, and some equity participation and technology transfer from both Japanese and South Korean corporations. ${ }^{6}$ If the private sector in Malaysia was unprepared to risk massive investment in these unproven ventures, Mahathir was more than ready to implement them via the Heavy Industries Corporation of Malaysia (HICOM), which came under the direct responsibility of the Prime Minister's office. There were many criticisms of the financial burdens and economic viability of the HICOM projects, including those voiced from within Mahathir's administration (Deputy Prime Minister Musa Hitam's reservations 
being the most important case in point). But Mahathir was insistent those heavy industries would bring spin-offs and linkages to the local economy, transfer technology from the advanced countries, and upgrade Malaysian technical, managerial and marketing skills. To his mind, Malaysia needed these benefits to emerge from the technological dependence, industrial backwardness and relative economic and political powerlessness typical of underdeveloped countries.

But if the state was made responsible for the heavy industrial drive, Mahathir introduced his privatization policy to reduce state expenditures and involvement in other areas of commerce and business. ${ }^{7}$ The Mahathir administration had inherited a state apparatus which had vastly expanded since the New Economic Policy (NEP) was promulgated in $1970 .{ }^{8}$ The bureaucracy employed a (non-military and nonpolice) workforce of 521,818 in 1983 compared with 139,476 in 1970, while total public sector expenditure increased from RM3.3 billion in 1970 to RM35.4 billion in 1982. And whereas there were an estimated 109 'public enterprises' in 1970, by 1980 there were 656.

Ideologically this enormous state expansion was justified as the necessary corrective to market-influenced and historically generated Malay economic backwardness and inter-ethnic imbalances. In practice, diverse state bodies, economic development corporations and bumiputera 'trust agencies', as well as their subsidiaries and associated companies, became involved in practically all sectors of the economy. But because they were simultaneously regarded as 'social enterprises', their deficits, debts and losses tended to be overlooked or absorbed by the state, and rationalized as the price of providing experience, employment and skills to the Malays in particular in order to attain the NEP's ethnically determined economic restructuring and social engineering goals.

Mahathir was ambivalent about the virtues of state economic expansionism. On the one hand, he had been the ideologue of state intervention for the 'constructive protection' of Malay economic interests. On the other hand, he had few illusions about the business acumen and the profit-making ability of bureaucrats. With privatization, Mahathir sought to discipline the bureaucrats in business and to widen the scope for private investment in the economy. However, in later years more complex issues bound up with the privatization became politically contentious. The 'Malaysia Incorporated' policy, modelled after the so-called 'Japan Incorporated', signalled an attempt to 
remould the relations between the public and the private sectors. Throughout the 1970s, when the NEP was earnestly implemented, each had regarded the other with suspicion; the public sector being seen as incompetent and unfair to non-Malay business, and the private sector being regarded as rapacious and uncaring about Malay economic weaknesses. But after more than a decade of earnest NEP implementation, the previous sharp dichotomy between a Malay-dominated public sector and a Chinese- (but also foreign-) controlled private sector no longer obtained. With state assistance, one of the goals of the NEP, the creation of a Bumiputera Commercial and Industrial Community (BCIC), had been partially attained, and now there was a substantial body of Malay businesses, some controlling key sectors of the economy. Under state regulation, some of the largest Chinese corporations, and most foreign investors had been obliged to restructure to accommodate (state and private) Malay equity and employment. So that his programme of modernization and industrialization would not be derailed by a continuing enmity between the state and capital, Mahathir meant Malaysia Incorporated to reorient bureaucratic and business attitudes towards each other.

The period 1981-83 was for the most part easy for Mahathir. In just two years he had won his first electoral mandate as Prime Minister without much difficulty, and had set a national agenda that was persuasive even as it was novel. In comparison with previous Prime Ministers, he exuded a sense of personal dynamism, far-sighted leadership and an 'open' populist style of politics. However, towards the end of 1983 Mahathir faced his first political crisis. In August 1983, Mahathir, UMNO, and the Barisan Nasional-majority parliament aided by a virtual mass media silence, had quietly managed the passage of several amendments to the constitution. The key amendment required the Malaysian King, the Yang di-Pertuan Agong, explicitly to give his assent to all acts of Parliament within fifteen days of their passage, failing which royal assent would be deemed to have been granted. This amendment appeared to be only a formality to prevent in law what had never occurred in practice, since none of Malaysia's constitutional monarchs had ever withheld royal assent.

The amendment was Mahathir's move to pre-empt the possibility that either of the two most likely successors to the Malaysian throne might, upon accession, interfere with parliamentary legislation. ${ }^{9}$ Moreover, Mahathir probably conceived of trimming the royal 
prerogative as a logical and legitimate part of his vision of transforming Malaysian society under a strong, popularly elected leadership. But in October certain veteran politicians from Mahathir's own party publicly denounced the amendment for its 'anti-royalist', if not 'republican', implications. From then on the Malay royalty began to draw emotional support from a large number of Malays who regarded the monarchy as, among other things, one of the most important symbols of the special position of the Malays. A crisis pitting a Malay executive against the Malay royalty ensued, which took the form of tense mass rallies in favour of one side or the other. The crisis broadened when the 'non-royalist' opposition took exception to another amendment which would permit the Prime Minister, instead of the Agong, to declare a state of emergency. This amendment, it was contended, smacked of authoritarian tendencies. For the most part, the crisis ended with a compromise in December 1993, when the Agong assented to the amendments while Mahathir agreed to pass further amendments more acceptable to the Malay royalty. While Mahathir appeared to have gained his most important objective of ensuring royal assent for future legislation, the battle between a Malay-led executive and the Malay royalty - which divided the Malay community and UMNO itself - was essentially stalemated, waiting to be replayed over other political issues.

\section{Phase 2, 1984-86: Scandals, Dissent and Recession}

With this 'constitutional crisis' of 1983, Mahathir's salad days were over. Now came, broadly, two series of political crises involving not the apex of Malaysian society but very much its 'grassroots'. The first set comprised several financial scandals, namely:

- the débâcle involving the Hong Kong-based Bumiputera Finance Malaysia Limited (BMF, a subsidiary of the state-owned Bank Bumiputera Berhad), leading to the loss of over RM2 billion and the murder of a senior BMF officer sent to investigate the BMF accounts;

- the losses associated with a state corporation, Maminco Sdn. Bhd., which had been used by the government to corner the international tin market with disastrous financial consequences;

- the Employees' Provident Fund (EPF) and the Makuwasa Securities Sdn. Bhd., which involved a manipulation of share 
allocations by the government to recoup some of the Maminco losses;

- the collapse of Pan-Electric Industries, which triggered a three-day suspension of the Singapore Stock Exchange and the Kuala Lumpur Stock Exchange and resulted in the conviction and subsequent imprisonment of the then MCA President, Tan Koon Swan, for criminal breach of trust; and

- the run on several deposit-taking co-operatives (DTCs), many of which were headed by MCA leaders and other political figures. ${ }^{10}$

Between 1984 and 1986, with these scandals being revealed one after another, and with the reluctance of the government to 'come clean' on any of them, the Mahathir administration was besieged by opposition parties, non-governmental organizations (NGOs), veteran public officers and retired Prime Ministers, and investors and depositors, collectively demanding executive accountability for loss of public funds and the prosecution of high-ranking bureaucrats and politicians suspected of impropriety and corruption.

In parallel with the financial scandals came a series of political difficulties and setbacks for the Mahathir administration, namely:

- the shock defeat in 1985 of the ruling Parti Berjaya-led Barisan Nasional government in Sabah by the Parti Bersatu Sabah (PBS), which precipitated a two-year crisis in Sabah - complete with a failed coup by the ousted Chief Minister, Harris Salleh, and the leader of the United Sabah National Organization (USNO), Mustapha Harun; political violence in the state; and a tense stand-off between the Joseph Pairin Kitingan-headed PBS state government and the federal government;

- the resistance, gaining strength from 1984-86, to plans for the location and operation of Asian Rare Earth Sdn. Bhd., a radioactive waste treatment plant, first in Papan, and then in Bukit Merah, Perak - which was backed by a mass mobilization of local residents and domestic and international NGOs;

- the September 1985 'Memali incident' in Kedah - where a police attempt to arrest an Islamic teacher led to a violent clash between the former and the latter's supporters, resulting in 17 fatalities (including four policemen), 29 injuries, and 160 arrests; and

- the sudden resignation, in February 1986, of Musa Hitam as Deputy Prime Minister and Deputy President of UMNO on grounds of an irreparable rift between him and Mahathir. ${ }^{11}$ 
The financial scandals cumulatively undermined the confidence of the urban, largely non-Malay, electorate in the integrity of the Mahathir administration. For this section of the population, which had substantially supported the Barisan Nasional in the 1982 general election, the many slogans and promises of reform had turned out to be hollow words. The political crises, including the constitutional crisis of 1983, exposed Mahathir's vulnerability on several fronts among Malay 'royalists' in and out of UMNO potentially rallying around Tengku Razaleigh Hamzah (former Finance Minister and a prince from Kelantan); the bumiputera Kadazans in Sabah; semi-rural Chinese residents in Papan and their NGO allies; PAS's Malay/ Muslim supporters and Islamic dissidents; and, finally, a sizeable section of the UMNO loyal to Musa.

Mahathir's political problems were compounded by the advent of an economic recession in 1985-86. After nearly 15 years of continuous growth, the economy contracted by $1.0 \%$ in 1985 and managed a $1.2 \%$ growth in 1986. There were at least three major components to the recession - a global collapse in commodity prices; a sharp rise in public, and especially foreign, debt; and a substantial decline in private investment. The commodities collapse had a tremendous overall effect on export earnings and state revenues. Export earnings had increased threefold between 1975 and 1980, and Malaysia's economic planners had forecast total export earnings of RM63.1 billion for 1985. The actual figure was only RM37.6 billion. Malaysia's public debt had risen in the 1970s as a result of deficit spending associated with NEP's implementation. But partly because of the expenditure on heavy industrialization and several large-scale infrastructural projects, and partly because of the appreciation of the yen against the US dollar following the G-7 Plaza Accord of 1985, total public debt which was RM34.16 billion in 1981 reached RM 87.06 billion in 1986. Private investment which had steadily increased during much of the 1970s and reached a high of RM13.35 billion in 1984, fell to RM10.23 billion in 1986. Foreign corporate investment alone fell from its peak of RM3.26 billion in 1982 to RM1.26 billion in 1986.

Until August 1986, Mahathir and his Finance Minister, Daim Zainuddin (appointed to replace Razaleigh Hamzah in 1984) responded to the recession in two basic ways. ${ }^{12}$ First, they imposed a structural adjustment type of restraint on most public spending. The 1985 federal government's development expenditure was RM6.76 
billion, just over half the 1983 figure of RM11.19 billion. Increases in operating expenditure were held down mostly by means of a job and wage freeze. Other than HICOM, the public enterprises were subjected to tighter budget constraints, closer monitoring, privatization and even closure. The Mahathir-Daim regime of fiscal austerity and contraction in state expenditure badly affected many social groups. Unemployment rose from less than $5.0 \%$ in 1982 to $8.5 \%$ in 1986. For the first time since the expansion of tertiary education under NEP, an estimated 30,000 to 40,000 Malay graduates were unemployed in view of the job freeze in the public sector. The prospect of bankruptcy was daunting for businesses dependent on state support and contracts, the most badly affected being smaller Malay companies. Reduced revenues made it difficult for the state to bail them out, and Mahathir and Daim reasoned that Malay businesses had to discard their 'subsidy mentality'. Senior bureaucrats suffered reductions in their allowances, while those managing public enterprises were publicly criticized for low productivity and incompetence, and asked to resign if they could not improve their performance.

A second response to recession by Mahathir and Daim consisted of new measures for the promotion of investment. In July 1985, guidelines for foreign equity ownership in manufacturing were liberalized. In December 1985, the Industrial Coordination Act, the main legal instrument of regulation under NEP, was amended to make it easier for manufacturers to start new projects, expand existing capacity, or diversify their range of products. The Promotion of Investments Act was passed in May 1986 and offered additional tax incentives for manufacturing, agriculture and tourism. A New Investment Fund was launched to allocate funds at preferential interest rates for new projects in these three sectors.

Despite the severe economic conditions and unfavourable political circumstances, Mahathir called for a general election in August 1986. By then the urban non-Malay electorate had largely been lost to the Barisan Nasional, and, in particular, its non-Malay component parties, the MCA and the Gerakan. Given the groundswell of urban and NGO disaffection with the Mahathir administration's handling of the financial scandals and the other political crises, a huge electoral gain was predicted for the DAP. It was also forecast that a resurgent PAS would inflict a significant defeat on UMNO in the rural Malay constituencies, perhaps aided by UMNO's internal 
disunity which also seemed likely to affect the efficacy of the party's electoral machinery. It was widely rumoured that the DAP and PAS, their ideological differences notwithstanding, would observe a tacit electoral pact against the Barisan Nasional.

However, the election only partially went according to forecast. The DAP secured $20 \%$ of the popular vote and won heavily against the MCA and Gerakan. But PAS performed miserably, winning just one out of 82 parliamentary seats against UMNO. In short, the election was decided by a number of factors: the manipulation of ethnic sentiment and tension by almost all parties in the months before the election; the Barisan Nasional's superior machinery; DAP's strong strategy; and PAS's ineffectual electoral campaigning. For his part, Mahathir, in accordance with the medical approach to politics which he professed to adopt, had virtually given up what was lost (the urban non-Malay vote) to retain what was critical (the Malay heartland). The Barisan Nasional was returned to power with its customary two-thirds majority in parliament, but mainly on the back of UMNO's overwhelming victory against PAS.

\section{Phase 3, 1987-89: Crises of Mahathirism}

Before August, those who still remembered Tunku Abdul Rahman's downfall following UMNO and the Alliance's heavy losses in the May 1969 election considered Mahathir's leadership itself to be at stake in the general election. Had UMNO performed badly against the PAS, Mahathir's position as party President would have come under intense questioning. Ironically, now that UMNO had triumphed, Mahathir's leadership came under attack from within the party.

In September and October, Mahathir decided to 'hold the NEP in abeyance' in order to stimulate the economy. The NEP contained a basic bumiputera equity ownership requirement that was deemed by the Malay community to be essential for its economic protection and advancement, but the requirement was generally unpopular with domestic and foreign non-Malay investors. The 'NEP in abeyance' meant a suspension of that ethnic equity requirement for private investment, first for foreign investors, and, then, for mostly domestic non-Malay investors. Arguing in the NEP idiom, Mahathir rationalized that economic 'growth' had to take precedence over NEP's ethnically determined 'distribution'. ${ }^{13}$ The Malay community (like 
the other communities) had suffered from the recession and the austerity measures imposed by Mahathir and Daim. Now its political, bureaucratic and business circles were divided by NEP's suspension. The exact alignments were complex, but roughly the larger and more successful Malay businesses, capable of weathering the recession somewhat better on their own, supported the move towards 'growth'. On the other hand, smaller Malay businesses and a high proportion of bureaucrats and public enterprise managers, rather more desperate for state interventionism and counter-cyclical measures, preferred the continuation of 'distribution'.

The conflicts in Malay society - thrown up by the constitutional crisis of 1983, Mahathir's bureaucratic reformism and economic modernization of 1981-83, the recession and the austerity measures of 1985-86, and the suspension of the NEP in late 1986 - were increasingly mediated through UMNO, the 'party of the Malays'. There, ideological and policy divergences intersected with personal grouses and ambitions to produce a brooding dissension against Mahathir's leadership of the party and the country. Mahathir was increasingly accused of economic mismanagement, cronyism, autocratic behaviour, and the subordination of the party to the government in policy matters. By February 1987, Musa and Razaleigh, formerly bitter foes in the party's Deputy President contests of 1981 and 1984 (both won by Musa), had found common cause in an anti-Mahathir alliance ahead of UMNO's triennial party election in April 1987. Razaleigh would challenge Mahathir for the President's post while Musa would defend his Deputy President's position against Ghafar Baba (whom Mahathir had appointed to replace Musa as the Deputy Premier). Faced with an unprecedented challenge against an incumbent President, UMNO's cabinet members, elected representatives, party veterans, delegates who would vote at the April annual general assembly, and its youth and women's wings, were split into 'Team A' (led by Mahathir-Ghafar) and 'Team B' (headed by Razaleigh-Musa).

Team $A$ and Team $B$ waged an all-out electoral war between February and April. ${ }^{14}$ On April 24, Team A won a very narrow victory. Mahathir defeated Razaleigh by 761 votes to 718 , while Ghafar won by 739 to 699 . The election for the 25 seats in the UMNO Supreme Council was likewise closely divided. Mahathir, who had pledged to remain as President even if he won by one vote, spurned 
the possibility of reconciliation by purging his cabinet of Team B members. In retaliation, a group of 12 Team B members (later reduced to 11) loyal to Razaleigh filed a suit in the High Court to have the April election nullified because a number of ineligible delegates had voted in the party election.

Before this 'UMNO-11' suit could be heard in court, a new political crisis loomed. As a result of UMNO's devastation of PAS, and DAP's defeat of MCA and Gerakan in the August 1986 general election, the electorate had been ominously split along distinct rural and urban lines, roughly corresponding to Malay and non-Malay divisions (in Peninsular Malaysia, at any rate). During the early Mahathir administration, the level of inter-ethnic, that is, 'Malay-Chinese', bickering over NEP and linguistic-cultural matters was low enough that most disputes were managed without serious repercussions by the Barisan Nasional leadership. But the Barisan Nasional framework for solving inter-ethnic disputes was severely strained in the late 1980s by UMNO's disunity and the MCA's weakness. When, therefore, a series of inter-ethnic disputes arose between June and October 1987 - by commission or omission, by design or accident UMNO's Team A and Team B, and MCA sought political salvation in 'Malay unity' and 'Chinese unity' respectively. And, finally, the Barisan Nasional's framework virtually fell apart when UMNO regarded it as a betrayal that MCA and the Gerakan should join the DAP and the traditionally dissident Chinese education movement in protesting a Ministry of Education exercise to appoint a number of nonMandarin-speaking headmasters in Chinese schools. Inter-ethnic oneupmanship was brought to brinkmanship when UMNO's plan to hold a 'mammoth rally' threatened to precipitate inter-ethnic bloodshed.

On 27 October 1987, Mahathir, as the Minister of Home Affairs, launched a nationwide police operation, codenamed 'Operation Lalang', which resulted in the detention of over 100 people, and the closure of three newspapers accused of fanning inter-ethnic discord.$^{15}$ The mass arrest of mostly opposition politicians, a handful of UMNO, MCA and Gerakan politicians, Chinese educationists, Islamic dissidents, and NGO representatives (many of this lastnamed group having nothing to do with the rising ethnic tension), was made under the Internal Security Act, which sanctioned detention without trial. With this sudden move, Mahathir quashed 
the possibility of bloodshed, because, almost as a quid pro quo, Mahathir cancelled the planned UMNO rally.

However, the UMNO-11 were undaunted in pushing their High Court suit. They had hopes that the Malaysian judiciary would uphold their cause, since it had in the mid- to late 1980 s decided several civil suits against the government. In February, the High Court delivered a stunning decision when it declared UMNO to be an illegal party because of the existence of several unregistered branches which had participated in electing delegates to the April 1987 UMNO assembly. Accordingly the High Court ordered UMNO's deregistration. Mahathir declined to appeal the court decision. The Registrar of Societies rejected an immediate attempt by Razaleigh and his allies to revive UMNO, but allowed Mahathir to set up 'UMNO Baru' (New UMNO). But because they had only wanted to have the party election nullified to pave the way for fresh elections, the UMNO-11 appealed to the Supreme Court.

Mahathir was not about to have his political fate decided by an 'independent judiciary'. During the tense period of 1986-88, Mahathir had periodically criticized the judiciary for demonstrating a bias against the executive. His public criticism of the judiciary had been occasioned by the executive's loss in several suits, primarily 'political' ones brought by the foreign press, leading figures from the parliamentary opposition (Lim Kit Siang and Karpal Singh), and NGOs (Aliran and the Papan Anti-Radioactivity Committee). Just before the UMNO-11 appeal was heard, the Lord President of the judiciary was suspended, impeached by a Special Tribunal for misconduct, and dismissed from office in August 1988. When five Supreme Court judges tried to come to the Lord President's aid, they, too, were suspended and impeached by a second tribunal which led to the dismissal of two Supreme Court judges. With the Malaysian judiciary so engulfed, the widening gyre of the crises of Mahathirism soon came to a close. ${ }^{16}$

In August 1988, the Supreme Court dismissed the UMNO-11's appeal. The most recalcitrant of the Team B dissidents, having been excluded from UMNO Baru, founded a new opposition party, Parti Semangat 46 (Spirit of 46 Party), headed by Razaleigh. The original UMNO, founded in 1946 as the organizational expression of Malay unity, was now irrevocably split. From late 1988 to 1989, the Team ATeam B conflict, as well as the dissent against the Mahathir admini- 
stration, was expressed in the form of several by-elections, between UMNO Baru and Semangat 46, and between the Barisan Nasional and a broad-based opposition. The by-elections had dramatic skirmishes and narrow victories but it was understood that the relative strengths of all sides would only be conclusively tested in the 1990 general election. Hence the most significant outcome of the by-elections was the shadowy emergence of two political coalitions in anticipation of the general election. Semangat 46 and PAS joined in one coalition, the Angkatan Perpaduah Ummah (APU, or the Muslim Unity Force). But the DAP would not enter a pact with APU so long as PAS was unwilling to drop its goal of an 'Islamic state'. Thus Semangat 46 and DAP, joined by a handful of smaller parties, formed a second coalition, the Gagasan Rakyat Malaysia (Gagasan).

\section{Phase 4, 1990-95: The Allure of Vision 2020}

Razaleigh led APU and Gagasan, hoping thereby to transform the Malaysian political system into a 'two-coalition system'. When Sabah's PBS defected from the Barisan Nasional (which it had joined in 1986) to the Gagasan on the eve of the October 1990 election, ${ }^{17}$ Razaleigh was confident that APU-Gagasan would be able to deny the Barisan Nasional its customary two-thirds majority in parliament if not oust the ruling coalition from power for the first time in Malaysian political history.

Purely as a conjecture, that might have happened had the 1985-86 recession 'deepened into 1990. By 1990, however, the Malaysian economy had experienced three years of strong recovery. A combination of improved commodity prices, an expansion in manufacturing export earnings, and an increase in private investment resulted in an average annual growth rate of $9.1 \%$, and a lowering of the unemployment rate from $8.5 \%$ in 1986 to $6 \%$ in 1990 . Mahathir could claim that the economic revival vindicated his policies and Daim's management - the austerity measures, promotion of investment efforts, privatization, and 'holding NEP in abeyance'. In the face of the economic performance of 1988-90, much of the dissent bred on scandals, recession and structural adjustment was laid to rest.

The politics of the 1990 election was thus played out on terrain familiar and favourable to the Barisan Nasional's traditional reliance on UMNO's strength, and on the coalition's claim to be the bastion of 
stability and development. When the electoral fervour settled, APUGagasan's expectations of severely denting the Barisan Nasional's hold on power were let down by Semangat 46 's dismal performance. Its representation in parliament fell from 13 seats to 8 , and though PAS gained an additional 6 seats, UMNO's position as the Barisan Nasional's bulwark was essentially unassailed. That the broad-based dissent of the 1980s had not entirely dissipated was shown by the PBS's retention of power in Sabah, APU's complete eclipse of UMNO in Kelantan, and the DAP's near defeat of the Barisan Nasional government in Penang. Despite these landmarks, Malaysia's political topography in 1990 was not essentially different from that of 1986: the Barisan Nasional was back in power with a two-thirds majority, UMNO was dominant, and Mahathir was in charge.

The year 1990 had long been regarded in the Malaysian public imagination as a critical year ever since the NEP was promulgated in 1970 and set to be implemented for 20 years. Of course, NEP's suspension in 1986 had altered things somewhat. Still it was widely assumed that the post-1990 period would see a new policy to guide Malaysia's long-term social and economic development. In February 1991, having gained twin economic and political triumphs in 1990, Mahathir unveiled a blueprint for Malaysia's future that has since been popularized as Wawasan 2020, or Vision $2020{ }^{18}$

In terms of economic policy, much of Vision 2020 was a repackaging of the policies of the early Mahathir administration - privatization, Malaysia Incorporated and industrialization. Ideologically, Vision 2020 retained many shades of early Mahathirism - a 'Malaysian nationalism', a freer capitalism, a moderate Islamization, and a scripted populism. The earlier goal of Nicdom being virtually realized by 1990, Vision 2020's principal goal was Malaysia's attainment of 'developed country status' by the year 2020. In sociopolitical terms, Vision 2020 envisaged the emergence of a Bangsa Malaysia, or a Malaysian Nation, that would gaze outwards in common purpose rather than focus on internal differences.

The NEP was supplanted by the National Development Policy (NDP). The NEP's commitment to an ethnic restructuring of the Malaysian political economy was not altogether abandoned, but the NDP assumed that the creation of a bumiputera commercial and industrial community had had substantial success, and that the future was based on wealth 'creation' rather than its distribution. 
Even if it was not entirely new, Vision 2020 quickly gained a generalized acceptance within Malaysian society. That had not been the case with the NEP, which had been offered in the name of 'national unity' but just as often generated inter-ethnic discord. When Mahathir's reforms, policies and favoured projects first appeared, they were sometimes greeted with scepticism. When privatization and deregulation were initiated, they met with opposition. But almost no one has greeted Vision 2020 with derision, and the post-1990 political debate found no trace of an alternative or competing agenda. Perhaps the 'grandiose' and 'universalizing' Vision 2020 fulfilled, and profited from, a long-felt need for a new social foundation for a post-1990 Malaysia - particularly after the traumas of NEP discord and the crises of Mahathirism.

The years 1991-95 saw an intermittent replay of some of the politics of the 1980s. In 1992, an incident involving the assault of a hockey coach by the Sultan of Johore precipitated a variation of the constitutional crisis of 1983. A unified UMNO that had already charged the Kelantanese royalty with interfering in politics to help APU to power in Kelantan in 1990 used the incident to pass legislation removing royal immunity from certain legal suits and grounds for prosecution. This time around, the royalty was unable to rally its previous support. ${ }^{19}$

After 1990, UMNO established itself in Sabah and rallied anti-PBS forces in the state. Over the next few years, the party and the Mahathir administration wreaked vengeance upon the PBS for the latter's defection in 1990, and upon Sabah for maintaining a nonBarisan Nasional state government. Several PBS leaders were prosecuted for alleged corruption; others were detained under the Internal Security Act for allegedly plotting the state's secession from Malaysia. The PBS's cohesion was undermined by the defection of some of its leaders. The formation of splinter parties weakened the PBS's Kadazan-non-Muslim alliance which had kept the party in power since 1985. As with all states that had been willing to maintain an opposition government in Malaysia's political history, Sabah was systematically starved of federally controlled development allocations and investment.

When state elections were called in early 1994, the PBS managed to hold on to its Kadazan base but won only by the sheerest of majorities. The result was insufficient to prevent the fall of Joseph 
Pairin Kitingan's 10-year government because of the defection of a few PBS state assembly representatives to the Barisan Nasional.

One far-reaching political development took place within UMNO in 1993, when the reconstituted party held its first election. Clearly no one was in a position to challenge Mahathir's leadership. Mahathir himself did not want a challenge against his Deputy, Ghafar Baba, who had stood by him since Musa's resignation, yet Mahathir could not prevent it. Anwar Ibrahim, one of three elected Vice Presidents from 1987, so outmanoeuvred Ghafar that the latter was compelled to withdraw from the fray even before the assembly was held. Anwar's rise was facilitated by the formation of his so-called 'Wawasan Team', comprising a set of younger candidates - Muhyiddin Yasin, Najib Tun Razak and Muhammad Muhammad Taib - for the Vice President's posts. And just as Anwar toppled Ghafar, the Wawasan Team swept the incumbents, Abdullah Badawi and Sanusi Junid, out of the top elected positions in UMNO.

There was much instantiated speculation that money and corruption had exerted an enormous influence in determining the outcome of the UMNO election. The party itself carried out no investigation, or at any rate, none that was publicized. Nor was there much concern the 'Wawasan' slate carried a 'Team B' echo from 1987 and presaged another cycle of factional fighting. What occasioned considerable excitement was Anwar's rise. Ever since Mahathir had brought him into UMNO from ABIM in 1982, Anwar had been considered to be a potential successor to Mahathir. After the UMNO election of 1993, Anwar lost no time in professing his loyalty to Mahathir. Mahathir in turn appointed Anwar as his Deputy Prime Minister. None the less, the UMNO election raised the critical question whether the protégé would turn challenger in the next party election of 1996.

The year 1994 brought expectations of another general election. The Barisan Nasional's triumph was a foregone conclusion. The period 1991-94 saw continued high economic growth, Sabah had fallen to the Barisan Nasional, and the APU-Gagasan pact had fallen apart after 1990. Yet Mahathir postponed the election to 1995, thus breaking the four-year election cycle which had been the practice since 1978. When the general election was finally held in April 1995, the only intriguing question was whether DAP could build on its gains in 1990 to form an opposition government in Penang. 
The 1995 Barisan Nasional campaign, the fourth under Mahathir's leadership, turned out to be its most successful. In Kelantan APU retained power but with a reduced majority. Elsewhere Semangat 46 suffered further reverses and could no longer pose any serious threat to UMNO. For the DAP, the election turned out to be its greatest disaster. In Penang, far from winning the state election, it retained only one out of its 14 state assembly seats. Throughout the rest of the country the MCA and the Gerakan routed DAP in the latter's customary urban strongholds.

There were two basic reasons for the DAP's defeat, notably its débâcle in Penang. First, the urban non-Malay electorate had reconciled itself with the Mahathirist programme and was not about to exchange economic prosperity for the deprivation that would certainly be visited upon a 'Penang in opposition'. Second, against his own brilliant judgement, the DAP leader, Lim Kit Siang, seemed to have badly misinterpreted the 'spirit of the 1990s'. Ideologically, the DAP campaign offered nothing to counter the impact of Vision 2020. Instead the party continued in vain to resuscitate the dissent of the mid-1980s. But that part of the 'politics of the Mahathir era' had ended way before 1995. The DAP paid the price of looking forlornly to the past while its erstwhile supporters had already been sold on the future.

With the passing of the 1995 general election, political interest returned to UMNO's 1996 election, and the question of Mahathir's successor. ${ }^{20}$ Rumours had been rife among journalistic and political circles of a rift between Mahathir and Anwar. In particular, it was frequently speculated that Anwar might be forced by his supporters to challenge Mahathir for the party presidency. Both Mahathir and Anwar denied that there was a rift between them, but Mahathir left nothing to chance and pre-empted any possibility of a challenge to his leadership with the consummate skill that had kept him in power for so long. At the 1995 UMNO annual general assembly, the party delegates passed a resolution that the posts of President and Deputy President should not be challenged in 1996. In principle, one or more of the party's 182 divisions could still snub Mahathir in 1996 by nominating Anwar for President, whether or not the latter accepted the nomination. But in May 1996, Mahathir immunized himself against any embarrassment, let alone challenge, with an UMNO Supreme Council ruling that no nomination - other than Mahathir for President and Anwar for Deputy President - would be accepted. 
Some observers had considered that Anwar had a firmer hold over the delegates to the 1996 UMNO assembly than Mahathir. Anwar's allies did win the presidency of the Pemuda UMNO (UMNO Youth) and of Wanita UMNO (the women's wing). But in fact the Wawasan Team no longer existed as a firm pact. Najib Tun Razak and Muhammad Muhammad Taib retained their Vice President's posts, but Muhyiddin Yasin, the one Wawasan Team candidate for Vice President from 1993 to remain a key Anwar ally, lost, and Abdullah Badawi recaptured the remaining post. Mahathir loyalists won strong control of the 25 elected seats in the Supreme Council. Mahathir's position was once again unassailable. In recent interviews with international magazines, Mahathir frankly indicated that he had 'no timetable for retirement'.

\section{Conclusion: An Interpretation}

Given their range, depth and complexity, the politics of the Mahathir era may be said to exhibit many leitmotifs, including:

- the emergence of new social, political and bureaucratic configurations and alignments resulting from the Mahathirist agenda of modernization, industrialization and privatization;

- the centralization of executive power vis-à-vis other institutions such as the monarchy and the judiciary, and opposition state governments;

- authoritarianism and the repression of civil society as desperate forms of control of popular dissent;

- the changing class and ethnic divisions of Malaysian society, most visibly expressed in the formation of a new alliance between a reformed state and a reconstituted capital; and

- the tensions inherent in Mahathir's ideological shift from the premises of the NEP to the parameters of Vision 2020.

It would be absurd to relate all the politics of the Mahathir era to these (or other) leitmotifs consistently and directly. Nor can all the above leitmotifs be necessarily subsumed under any single, overarching theme. It seems reasonable, however, to view much of the politics of the Mahathir era as the politics of social and political transformation attendant upon the Malaysian experience of late industrialization which took place under the Mahathir regime. 
Between 1957 and 1969, the Malaysian political economy was maintained in its relative laissez-faire state, which was socially characterized by an ethnic division of labour (and wealth ownership) inherited from colonial times, and which proved to be politically explosive in May 1969. During the NEP decade of the 1970s, the Malaysian state intervened massively in the economy to resolve what Mahathir himself popularized as the 'Malay dilemma' that is, the political need to delay the country's progress in order to alleviate the relative backwardness of the Malay community. In the ensuing transformation of the Malaysian political economy, the state made considerable progress in reforming Malay and Malaysian society - principally by engineering a new class of capitalists, bureaucrats and professionals (the so-called Bumiputera Commercial and Industrial Community).

By the time Mahathir came to power, however, further economic progress seemed to him to be held back by the proliferation of unwieldy enterprises, and the rift between a Malay-dominated state and non-Malay-controlled capital. It fell to Mahathir's personal boldness and nationalistic impulses to unleash a programme of economic modernization, heavy industrialization and privatization as the path to Nicdom. Much of this Mahathirist programme was modelled after the East Asian experience of carrying out late industrialization under the direction of a strong state. Much of this programme, in Mahathir's view, also required a 'clean, efficient and trustworthy' leadership, combined with mass mobilization.

For the combination of leadership and popular participation to work, Mahathir prescribed the transformation of social attitudes, characterized by the inculcation of a 'work ethic' and the infusion of modernist. Islamic values (especially towards education, thrift, labour and piety). Such an attitudinal-spiritual-value transformation most directly and deeply affected the Malay community, because Mahathir - at first by design and then when compelled by recession required of the Malay bureaucrats, professionals and business people that they should discard their NEP-bred dependence on state protection, preferential treatment and sponsorship. And when faced with the 1985-86 recession, Mahathir revealed his tenacity as a politician, his pragmatism as an economic planner, and his adaptability as an ideologue. It was indicative of his radical departure from any dogmatic commitment to the 'Malay dilemma' that he 
gambled on NEP's suspension rather than its entrenchment. In the process, his and Daim's regime of structural adjustment intensified the fissures within Malay society, fissures which found their institutional expression in UMNO's factionalism of the late 1980s.

If all this suggests a Mahathir very much in control of events, a good part of the control was in fact lost to the outpouring of popular dissent in the mid-1980s. The dissent issued from different quarters and was expressed through different democratic avenues available in the Malaysian polity - state election (Sabah 1985-86), general election (DAP's gains in 1986), local community organization (Papan and Bukit Merah), NGOs (the 1986 Anti-Official Secrets Act campaign), party election (UMNO in 1987), and the courts (1986-88). As Mahathir and his administration battled for political survival, the strong state that he regarded as being ideal for guiding economic transformation became, in his eyes, the essential instrument for repressing social and political dissent.

Thus opened an authoritarian phase of Mahathirist politics in 1987, as various democratic forms of opposition were progressively crushed, notably through the purge of the Team B dissidents, the mass arrests of October 1987, and the assault on the judiciary in 1988. The political ferment continued and ended during the 1990 general election, when the Semangat 46-led coalitions failed to alter radically the power structure controlled by the Barisan Nasional.

During the 1990s, key features of the political economy which Mahathir inherited in 1981 were radically altered. Privatization, deregulation and economic liberalization penetrated areas formerly controlled by the state, especially physical infrastructure, utilities, higher education and health-care services. With the expansion of economic opportunities created by these changes and the high growth conditions, the NEP concerns with ethnic wealth distribution have mostly been dissipated.

Socio-economic modernization has also taken on new meanings, such as a partial reversal in language and education policies to boost the position of English as the language of commerce and industry, the corporatization of local universities, and the emphasis on human resource development to keep apace of the 'demands of the age of information technology'. Some of these measures provoked lowlevel Malay linguistic-cultural resistance to a perceived downgrading of the status of the Malay language, but simultaneously eased 
non-Malay grievances over ethnic quotas for tertiary educational opportunities and worries about the position of the traditional 'independent Chinese schools'.

During the 1990s too, nationalism has been imbued with strong market dimensions, chiefly the export of Malaysian capital to other, less developed countries. Pockets of opposition and dissent remained, such as many NGOs' criticisms of money politics, nontransparent privatization contracts, treatment of foreign labour, and even foreign policy. In other words, many old political problems found new economic solutions. Undoubtedly, there had been opposition to mammoth projects such as the Bakun hydro-electric project, local resistance to large-scale state acquisition of land for privatized projects, and urban squatters' organization against dislocations caused by an untrammelled property market. But these pockets of dissent found no focus to galvanize them into anything like the opposition movements of the previous decade. Instead, the conditions of rapid industrialization, high economic growth and unprecedented levels of wealth facilitated the sweeping ideological triumph of Mahathirism, known by its official names of Vision 2020 and the National Development Policy. By 1996, Mahathir had won back just about everything that he had lost in the mid-1980s: the power of the monarchy was trimmed in 1993, PBS was toppled in 1994, and the DAP was humiliated in 1995. Finally, APU broke up in 1996 and Razaleigh and Semangat 46 returned to UMNO.

Khoo Boo Teik, Lecturer, School of Social Sciences, Universiti Sains Malaysia, 11800 Minden, Pulau Pinang, Malaysia. Tel: (60) 604-657 7888; Fax: (60) 604-657 0919, e-mail: booteik@usm.my.

\section{NOTES}

1 This article is part of a larger project ('Discourses and Practices of Democracy in Southeast Asia') being conducted by the Research and Education for Peace Unit, Universiti Sains Malaysia (REPUSM) in association with the Goteborg University Centre for East and Southeast Asian Studies (GESEAS). Funding from Sida, Sweden, which supported the research and preparation for this article is gratefully acknowledged.

2 That notion, never adequate for interpreting Malaysian society, is particularly problematic when simplistically applied to the politics of the Mahathir era, as may be suggested by two cases from Table 1. The political struggle between a chiefly Malay executive and a 
wholly Malay royalty which flared up in 1983-84 and was replayed in 1992-93, and the battle between the Mahathir- and Tengku Razaleigh Hamzah-led factions within the ruling United Malays National Organization (UMNO), which took different forms but lasted a decade, cannot properly be understood by recourse to ethnic factors.

3 Given the retrospective character of this article, much of its content was drawn, but not merely reproduced, from my previous writings on Malaysian politics under Mahathir and related subjects, namely, Khoo Boo Teik, Paradoxes of Mahathirism: An Intellectual Biography of Mahathir Mohamad. Kuala Lumpur: Oxford

University Press, 1995; Jomo K.S., Khoo Boo Teik \& Chang Yii Tan, 'Vision, Policy and Governance in Malaysia', in Leila Frischtak \& Izak Atiyas (eds.) Governance, Leadership, and Communication: Building Constituencies for Economic Reform. Washington, D.C.: World Bank, 1996: 65-89; Khoo Boo Teik, 'Democracy and Authoritarianism in Malaysia since 1957', in Anek Laothamatas (ed.) Democratization in Southeast and East Asia. Singapore: ISEAS, 1997: 46-76; and Khoo Boo Teik, 'Between Law and Politics: The Malaysian Judiciary since 1957', in Jayasuirya Kanishka (ed.) Legal Institutions and the Rule of Law in East Asia. Melbourne: Routledge \& Kegan Paul, forthcoming.

4 Briefly, Anwar Ibrahim went for Islamization while Kerk Choo Ting thought Mahathir's 'liberalism' made it worthwhile to work for Chinese interests from within the Barisan. Others drawn to Mahathir were Kassim Ahmad of the old Malay left, who saw something in Mahathir's nationalism, and Syed
Hussein Alatas, a founder of the Gerakan Rakyat Malaysia, who was impressed by the anti-corruption campaign.

5 For a useful collection of essays on Mahathir's economic policies up to the mid-1980s, see Jomo K.S. (ed.) Mahathir's Economic Policies, 2nd edition. Kuala Lumpur: Insan, 1989.

6 Two contemporary critical studies of the Proton and Perwaja projects are Chee Peng Lim, 'The Proton Saga -- No Reverse Gear: The Economic Burden of the Malaysia Car Project', in Jomo K.S. (ed.) Mahathir's Economic Policies. Kuala Lumpur: Insan: 48-62, and Kit Machado, 'Japanese Transnational Corporations in Malaysia's StateSponsored Heavy Industrialization Drive: The HICOM Automobile and Steel Projects'. Pacific Affairs, 62 (4) (Winter 1989-90): 504-31.

7 An official statement of the privatization and Malaysia Incorporated policies was given in Mahathir Mohamad, 'Malaysia Incorporated and Privatization: Its Rationale and Purpose', in Mohd. Nor Abdul Ghani et al. (eds.). Malaysia Incorporated and Privatization: Towards National Unity. Petaling Jaya: Pelanduk Publications, 1984: 1-6.

8 James V. Jesudason, Ethnicity and the Economy: The State, Chinese Business and Multinationals in Malaysia. Singapore: Oxford University Press, 1989; Jomo K.S., A Question of Class: Capital, the State and Uneven Development in Malaya. Singapore: Oxford University Press, 1986; and Ozay Mehmet, Development in Malaysia: Poverty, Wealth and Trusteeship. London: Croom Helm, 1986 contain analyses of the expansion of state enterprises from differing theoretical approaches. 
9 For political background and discussions of legal issues related to this amendment, see Roger Kershaw, 'Malay Monarchy since Yahya Petra: Riding for a Fall?'. Contemporary Review, 245 (1424) (September 1984): 113-20, and H.F. Rawlings, 'The Malaysian Constitutional Crisis of 1983'. International and Comparative Law Quarterly, 35 (2) (April 1986): 237-54.

10 Detailed analyses of these scandals are contained in Khoo Boo Teik, Paradoxes of Mahathirism, pp. 209-19.

11 Ibid., pp. 219-31.

12 For an excellent contemporaneous analysis of the political tensions generated by the Mahathir-Daim measures, see Khoo Khay Jin, 'The Grand Vision: Mahathir and Modernization', in Joel Kahn \& Francis Loh Kok Wah (eds.) Fragmented Vision: Culture and Politics in Contemporary Malaysia. Sydney: Asian Studies Association of Australia in association with Allen \& Unwin, 1992: 44-76.

13 An original, non-academic study of the debate over the NEP may be found in Malek Marican, 'The NEP from a Private Sector Perspective'. Paper presented at the seminar, 'Dasar Ekonomi Baru Selepas 1990: Peranan Sektor Korporat Awam', Kuala Lumpur, 24-26 March, 1987.

14 For background and a close observation of the UMNO election, see Shamsul A.B., 'The 'Battle Royal': The UMNO Elections of 1987', in Southeast Asian Affairs 1988. Singapore: ISEAS, 1988: 170-88.

15 Some documents and analyses related to Operation Lalang are provided in Committee against Repression in the Pacific and Asia, Tangled Wed: Dissent, Deterrence and the 27th October 1987 Crackdown in
Malaysia. Haymarket: NSW, CARPA, 1988.

16 H.P. Lee, Constitutional Conflicts in Contemporary Malaysia. Kuala Lumpur: Oxford University Press, 1995, and Rais Yatim, Freedom under Executive Power in Malaysia: A Study of Executive Supremacy. Kuala Lumpur: Endowment, 1995. Both contain recent in-depth studies of the 1988 crisis of the Malaysian judiciary.

17 There is no space here to discuss the complexities of the Sabah political situation, for which, see Francis Loh Kok Wah, 'Modernization, Cultural Revival and Counter-Hegemony: The Kadazans of Sabah in the 1980', in Joel Kahn \& Francis Loh Kok Wah (eds.) Fragmented Vision: Culture and Politics in Contemporary Malaysia. Sydney: Asian Studies Association of Australia in association with Allen \& Unwin, 1992: 225-53.

18 The significance of Vision 2020 as the maturation of Mahathirist ideology is explored in Khoo Boo Teik, Paradoxes of Mahathirism, pp. 327-31.

19 See Roger Kershaw, 'Shattered Symbiosis: The Road to Conflict between Malay Nationalism and Monarchy'. Internationales Asienforum, 24 (3-4) (November 1993): 283-310, and Syed Husin Ali, Isu Raja dan Pindaa Perlembagaan. 2nd edition, Petaling Jaya: S. Husin Ali, 1993.

20 A study of the UMNO election of 1996 is given in Khoo Boo Teik, 'Challenges and Upsets in Politics and Other Contestations'. in Daljit Singh (ed.) Southeast Asian Affairs 1997. Singapore: ISEAS, 1997: 163-84. 